\title{
Adaptation and Validation of Safety Attitude Questionnaire Ambulatory (SAQ-A) in Indonesian Primary Health Care Facilities
}

\author{
Adaptasi dan Validasi Safety Attitude Questionnaire-Ambulatory (SAQ-A) pada Fasilitas Pelayanan \\ Kesehatan Primer di Indonesia \\ Ngatoiatu Rohmani ${ }^{1}$, Ike Wuri Winahyu Sari ${ }^{2}$ \\ ${ }^{1}$ Department of Nursing Management, Nurse Internship Program, Universitas Jenderal Achmad Yani \\ Yogyakarta \\ ${ }^{2}$ Department of Medical-surgical Nursing, Nursing Education, Universitas Jenderal Achmad Yani Yogyakarta
}

DATA OF ARTICLE:

Received: 4 Dec 2018

Reviewed: 20 Mei 2019

Revised: 24 Jun 2019

Accepted: 29 Jun 2019

*CORRESPONDENCE:

rahmanigp@gmail.com

DOI:

10.18196/mm.190228

TYPE OF ARTICLE:

Research

\begin{abstract}
Prevention of patient safety incidence needs to be pursued by the management committee of healthcare institutions by changing the behavior of healthcare providers to create a patient safety culture. Also, safety culture evaluation needs to be done to assess the implementation of the culture by healthcare providers. For this reason, a valid and reliable instrument is required in order to be accepted and used in Indonesia as a tool to measure of safety culture attitude in healthcare facilities. This study aimed to adopt the Safety Attitude Questionnaire Ambulatory (SAQ-A) instrument to Indonesian. The study was carried out in 5 stages, they were: The translation stage, translation result synthesis, back-translated, review of 3 experts to obtain content validity index (CVI) and questionnaires trial which is conducted in 6 Puskesmas, i.e., Puskesmas Pandak I, Puskesmas Pajangan, Puskesmas Godean I, Puskesmas Kalasan, Puskesmas Tempel I and Puskesmas Minggir. Purposive sampling technique was selected to obtain 30 respondents based on inclusion criteria: She/he works in research location and has experience at least for one month, permanent/ contract employee, and not on sabbatical leave or other permission. Data were analyzed using the Content Validity Index (CVI) and Alpha Cronbach Coefficient. The validity test result of the Indonesian version of SAQ-A based on I-CVI and S-CVI was 1.00 with Cronbach's alpha reliability value from the six dimensions in the questionnaire within range of $\alpha 0.612$ 0.881 . The reliability test result of the full item on the Indonesian version of the SAQ-A questionnaire was $\alpha 0,914$. It was concluded that the Indonesian version of the SAQ-A questionnaire is a valid and reliable questionnaire which can be used as a tool to measure safety culture attitudes of healthcare providers in primary healthcare facilities.
\end{abstract}

Keywords: Instrument Adaptation; Safety Culture; Safety Questionnaire; SAQ 
terdiri dari Puskesmas Pandak I, Puskesmas Pajangan, Puskesmas Godean I, Puskesmas Kalasan, Puskesmas Tempel I dan Puskesmas Minggir. Responden berjumlah 30 orang yang dipilih menggunakan teknik purposive sampling dengan kriteria inklusi telah bekerja minimal 1 bulan di lokasi penelitian, merupakan pegawai tetap ataupun kontrak, dan tidak sedang dalam masa cuti atau ijin. Analisis data pada penelitian ini menggunakan Content Validity Index (CVI) dan rumus koefisien Alpha Cronbach. Hasil uji validitas kuesioner SAQ-A versi Indonesia berdasarkan I-CVI dan S. CVI sebesar 1,00 dengan nilai reliabilitas Cronbach's alpha dari 6 dimensi dalam kuesioner tersebut dalam rentang $\alpha$ 0,612 - 0,881. Hasil uji reliabilitas seluruh item SAQ-A versi Indonesia sebesar $\alpha$ 0,914. Disimpulkan bahwa kuesioner SAQ- A versi Indonesia (ISAQ-A) merupakan kuesioner yang valid dan reliabel untuk mengukur perilaku budaya keselamatan oleh petugas kesehatan di fasilitas pelayanan kesehatan primer.

Kata Kunci: Adaptasi Instrumen; Budaya Keselamatan; Kuesioner Keselamatan; SAQ

\section{INTRODUCTION}

Safety is one of the important issues and is the center of attention in various professional organizations, including healthcare organizations. Patient safety is an important component to assess the quality of healthcare services and as a foundation in providing quality services to clients. Lack of attention and concern for patient safety certainly impacts not only patients but also nurses and hospitals as healthcare providers. Research from two major hospitals in Australia reported that 35.7\% of the incidence of medical errors caused by an intravenous drug error caused a decrease in body function resulting in an extension of the day of treatment, surgery, and loss of permanent body function. ${ }^{1}$ Meanwhile, from the nurses, some nurses who have practiced medical errors experienced post-traumatic stress even years after the incident. ${ }^{2}$ In addition, nurses also get sanctions from the institution of nursing staff. The impact of this medical error incident for hospitals is a decrease in public trust in health services and a decrease in interest in the use of hospital services. ${ }^{3}$

The efforts to minimize incidents on patient safety need to be carried out by the hospital management, which aims to change employee behavior to create a patient safety culture. The patient safety culture is a combination and incorporation of individual patterns and organizational behavior based on beliefs and values that aim to reduce events that endanger patients in a sustainable manner. ${ }^{4}$ Safety culture aims to; (1) creating behavioral norms, (2) reducing the incidence of accidents and injuries, (3) ensure that every member of the organization prioritizes patient safety issues, (4) fosters members' interest in sharing ideas and beliefs related to risks, impacts of events and conditions that worsen health, (5) increasing community commitment to primary safety, (6) increasing the ability to design an organization's health and safety program. ${ }^{4}$

Patient safety culture in a healthcare facility can be known by conducting a series of an evaluation study in a hospital. If a hospital has a high integrity of safety culture, then the hospital staff have prioritized patient safety in that place. Improving patient safety culture is the need for health institutions to improve patient safety and improve the competitiveness of health services. ${ }^{5}$

Research on the culture of patient safety shows that many safety culture assessment instruments are developed in English. ${ }^{5,6,7,8}$ One assessment instrument that has been adopted in various languages is the Safety Attitude Questionnaire (SAQ) developed by Sexton in 2006. ${ }^{9}$ The initial version of the questionnaire contains 60 questions including 30 core questions that can be used in all clinical settings. Furthermore, a short version of SAQ was developed, which consisted of only 30 core items. The SAQ questionnaire has several versions that are tailored to the health facilities being assessed. SAQ-Ambulatory Version (SAQ-A) is one of the questionnaires used to evaluate the patient safety culture in the original healthcare order. $^{10}$ SAQ-A was developed by Modak et al. (2007), 11 contains 62 items of questions that are almost the same as SAQ which are divided into 6 domains, namely: 1) Climate of cooperation, 2) safety culture scale, 3) perceptions of management, 4) job satisfaction, 5) recognition of stress, 6) process of ambulatory care. Confirmatory Factor Analysis (CFI) and internal consistency show that SAQ-A has been valid and reliable to be used as the instrument for assessing patient safety culture.

Research to measure patient safety culture is not found in Indonesia. Some studies have used SAQ as an instrument to assess patient safety from health workers in inpatient and outpatient units of a hospital. ${ }^{12,13}$ Although the research of Emilia $(2011)^{12}$ explained that the SAQ-A instrument had gone through internal reliability before being used and the questionnaire was reliable with the value of job satisfaction (alpha $=0.80$ ), perception of management (alpha $=0.77)$, safety climate (alpha $=0.67)$, working conditions (alpha $=0.63$ ), stress recognition (alpha $=0.73$ ), and working climate (alpha $=0$, 84), the research did not explain further about the process of adaptation and instrument validation according to the right theory and methodology. An 
instrument that can be used in culture, language, and by other countries should need to be translated, adapted and validated through careful planning and the right methodological approach. ${ }^{14}$

This study aims to adapt the SAQ-A instrument to gain reliability and validity in order to be accepted and used in Indonesia as an evaluation of the practice of patient safety culture that is useful for improving the quality of healthcare services.

\section{MATERIAL AND METHOD}

The population in this study were healthcare professionals consisting of nurses, doctors, midwives, laboratory staff and pharmacists working at Puskesmas Pandak I, Puskesmas Pajangan, Puskesmas Godean I, Puskesmas Kalasan, Puskesmas Tempel I dan Puskesmas Minggir. The sample was selected using a random sampling technique with inclusion criteria, namely permanent and contract health workers, had worked at least one month at the research location and were not on leave or permission. The number of samples in this study was 30 respondents.

The adaptation process of the SAQ-A instrument is carried out in five stages, namely the translation stage, the synthesis stage of the translation results, the back translate stage, the review stage of the expert committee, and the instrument trial stage. $^{15}$

At the translation stage, the original instrument was translated by two people where the first translator was an individual who understood English and the SAQ-A concept, while the second translator was an individual who did not understand the SAQ-A construct called naïve translator. In this study, researchers chose a graduate of English Literature Education who had worked in an Englishlanguage educational institution as a naïve translator.

In the synthesis stage of the translation results, the translation results from the naïve translator are discussed to determine the core of the two translations. At this stage, the translation results are the sentences that are closest to the description according to the original questionnaire.

In the next step, i.e., back-translated, the synthesis of the translation results were then re-translated into English by the Language Training Institute (Pusat Pelatihan Bahasa) at Universitas Muhammadiyah Yogyakarta.

At the review stage of the expert committee, the results of the back translate are then submitted for the review process by experts who are considered to understand the SAQ-A concept to be assessed based on the content of the instrument. The expert committee consists of 3 people (2 lecturers of Nursing, Faculty of Health, Universitas Jenderal A. Yani Yogyakarta, one nurse from Wates Hospital who has experienced more than ten years).

Each item was evaluated and assessed using four ordinal scales ( 1 = irrelevant, 2 = slightly relevant, 3 = quite relevant, 4 = very relevant) as a result of the validity test. Items with a CVI value of less than 0.78 will be considered for revision.

The last stage is the instrument testing phase. Testing of assessment instruments was carried out to health workers in 6 Puskesmas in the Yogyakarta area. The trial was conducted to test the reliability of the Indonesian version of the instrument. The reliability test uses the Alpha Cronbach coefficient formula because the assessment instrument has several answer choices. Cronbach's Alpha score of less than 0.7 indicates the instrument is not reliable.

\section{RESULT}

The translation results of SAQ-A in Indonesian, which is later translated by the PPB Institution did not experience significant changes in the meaning of each item. The Indonesian version of SAQ-A before validity can be seen in Table 1.

The validity test of the Indonesian version of SAQ-A is the third stage of the adaptation process carried out through content validity based on reviews from experts to evaluate the clarity and relevance of each item in the questionnaire by three experts. These three experts consist of Nursing Management lecturers of Universitas Jenderal A. Yani Yogyakarta, Community Nursing lecturer Universitas Jenderal A. Yani Yogyakarta, and nursing staff at Wates Hospital, Kulon Progo, Yogyakarta. At first, the results of the item review (S-CVI) by three experts obtained a value of 0.98 , which indicates that the instrument cannot be considered valid. For this reason, the researchers attempted to make improvements according to the advice and input of experts to obtain a $1.00 \mathrm{~S}-\mathrm{CVI}$ value so that the instrument was declared valid in content based on expert consensus. The final value of I-CVI and S-CVI after the revision is 1.00 .

The Indonesian version of the SAQ-A reliability test was analyzed using Cronbach's Alpha and categorized by seven domains, namely: climate of cooperation, climate of safety, perceptions related to management, job satisfaction, working conditions, stress recognition, and outpatient care processes (Table 2). Also, validity tests are presented as a whole in the Indonesian version of SAQ-A shown in Table 3 .

Table 2. shows that stress recognition domain is the domain that has the lowest reliability compar 
Table 1. Results of Translation of SAQ-A before Testing Validity

\begin{tabular}{|c|c|}
\hline No & Item \\
\hline 1 & In this office, it is difficult to talk or express opinions if I have a problem with patient care * \\
\hline 2 & Doctors and nurses work together as a team that can coordinate well \\
\hline 3 & $\begin{array}{l}\text { Disagreement in the office can be resolved appropriately (for example not about what is right but what is } \\
\text { best for the benefit of the patient) }\end{array}$ \\
\hline 4 & Input from nurses can be well received in this office \\
\hline 5 & I have the support I need from other employees to treat patients \\
\hline 6 & It's easy for employees in this office to ask when there's something they don't understand \\
\hline 7 & $\begin{array}{l}\text { I was encouraged by my co-workers to report if there were problems with patient safety that I might } \\
\text { encounter }\end{array}$ \\
\hline 8 & The culture in this office makes it easy to learn from other people's mistakes \\
\hline 9 & Medical errors can be handled appropriately in this office \\
\hline 10 & I know the right way to ask directly about patient safety in this office \\
\hline 11 & I get the right feedback about my performance \\
\hline 12 & I will feel safe if I am treated here as a patient \\
\hline 13 & In this office, I find it difficult to discuss mistakes * \\
\hline 14 & Senior management in this office does a good job \\
\hline 15 & Management in this office does a good job \\
\hline 16 & I was given sufficient and timely information about the events in the hospital that might affect my work \\
\hline 17 & The number of employees in this office is sufficient to treat the patients \\
\hline 18 & This office is a good place to work \\
\hline 19 & I am proud to work in this office \\
\hline 20 & I feel that I am part of a large family in this office \\
\hline 21 & The moral value in this office is high \\
\hline 22 & I like my job \\
\hline 23 & This office does a good job in training new employees \\
\hline 24 & This office constructively handles doctors and medical workers who have problems \\
\hline 25 & All information needed for diagnosis and therapy decisions is routinely available to me \\
\hline 26 & The training participants in my major study were adequately supervised \\
\hline 27 & When my workload is excessive, my performance is interrupted \\
\hline 28 & I tend to make mistakes in tense or unfriendly situations \\
\hline 29 & Fatigue interferes with my performance during emergencies (for example blue code or heart failure) \\
\hline 30 & I can't effectively work when I'm too tired \\
\hline 31 & I am satisfied with the referral in my office, currently \\
\hline 32 & There is sufficient and timely provision of patient information among the main doctors and specialists \\
\hline 33 & Medicines are refilled promptly \\
\hline 34 & The drug is prescribed appropriately \\
\hline 35 & Abnormal test results are often lost or missed * \\
\hline
\end{tabular}

Table 2. Cronbach's Alpha Test Results Per Domain in the Indonesian Version of SAQ-A

\begin{tabular}{clcc}
\hline No & \multicolumn{1}{c}{ Aspect/ Domain } & No Item/question & A Value \\
\hline 1 & Cooperation climate & $1-6 / 6$ questions & 0,869 \\
2 & Safety climate & $7-13 / 7$ questions & 0,773 \\
3 & Perception related to management & $14-17 / 4$ questions & 0,684 \\
4 & Job satisfaction & $18-22 / 5$ questions & 0,881 \\
5 & Working conditions & $23-26 / 4$ questions & 0,787 \\
6 & Introduction to Stress & $27-30 / 4$ questions & 0,612 \\
7 & Outpatient care process & $31-35 / 5$ questions & 0,649 \\
\hline
\end{tabular}

Table 3. Cronbach Alpha Results in all Indonesian Versions of SAQ-A

\begin{tabular}{cc}
\hline Cronbach's Alpha & Nof Items \\
\hline 0,914 & 35 \\
\hline
\end{tabular}

ed to other domains $(\alpha=0.612)$. In addition, there are at least 3 domains with alpha values be-low 0.7 , which indicate that the item is considered quite reliable. However, the result of the reliability test 
for all items in the Indonesian version of the SAQ-A questionnaire in Table 3. shows a very relia-ble value $(\alpha=0.914)$.

\section{DISCUSSION}

The translation results of the Indonesian version of SAQ-A that have been carried out in this study did not change the meaning of the original SAQ-A. This was proved with no significant changes in the sentence based on the results of the back translation conducted by the Language Training Center in one of the educational institutions. Word changes do occur in several words such as the word "physicians" that turn into the word "doctors," the word "personnel" becomes "employees," while the word "colleagues" becomes "coworkers".

The process of adaptation with the back translation method is the most widely used method, which is also combined with the forward and backward translation methods. ${ }^{9}$ Some countries that use the back translation method in the process of adaptation of the SAQ instruments include Turkey, India, the Netherlands, and Norway. In line with this study, several other studies also found the word changes in the original version of the SAQ adaptation process, ${ }^{9}$ for example changes in "physiccians" become "doctors" in the adaptation into Turkish. ${ }^{18}$.

After the translation process, all items in the original version of SAQ-A were reviewed by 3 experts to obtain validity test scores. The final result of I-CVI and S-CVI based on the 3 experts was 1.00 which proved that the Indonesian version of the SAQ-A instrument was declared valid. If there are only 5 or 3 experts in evaluating content validity, the $\mathrm{I}-\mathrm{CVI}$ value that must be obtained is at least 1.00. ${ }^{16}$ However, if there are more than 6 experts, the I-CVI value is not less than 0.78 . The process of obtaining S-CVI values is certainly through a revision process on some items that are considered by experts to be less relevant. There were 2 items of questions with major revisions, namely on statement items 1 and statement items 3. The first item statement 1 was "In this office, it is difficult to talk or express opinions if I have a problem with patient care" became "At the place where I work, it is difficult to talk or express opinions to colleagues and / or the boss when I have problems with patient care". Meanwhile the statement item 3 previously which was "Disagreement in the office can be resolved appropriately (for example not about what is right but what is best for the benefit of the patient)" was revised to be "Disagreement in the problem of patient care in this unit can be resolved through collective consultation for the benefit of patients".

The method of content validity was also carried out by Hamid, Kar and Murad ${ }^{5}$ in the process of adaptation of the SAQ instrument. $n$ the study, seven experts were selected based on convenience sampling to provide a value with 4 Likert scales: (1) relevant; (2) irrelevant; (3) relevant but needs a little revision, and (4) is very relevant. The $\mathrm{CVI}$ value below 0.8 indicates that the item must be revised. In the process, word changes were also conducted by several researchers, such as adding the word "their" to the question item "senior management of this office is doing a good job" based on CVI values that were below the standard. ${ }^{5}$ Changes or additions to the words in the original sentence are conducted to make the sentence clearer and easily understood by the respondent according to the language in the country adopting the instrument. This is in line with the process of adaptation of the SAQ in Norwegian and Dutch, where the process also uses content validity to avoid misunderstandings in interpreting the meaning of each item in the instrument. ${ }^{10,17}$

Cronbach's Alpha reliability test results showed that the Indonesian version of the SAQ-A questionnaire was reliable enough to measure safety practices in primary health care facilities such as Puskesmas, with a range of values a 0,612-0,881 (Table 2.). In this study, the dimensions of job satisfaction are dimensions with the highest reliability value of 0.881 . Similar results were also found in the study by Haerkens et al. (2016), ${ }^{17}$ and Kaya et al. (2010), ${ }^{18}$ in which in both studies the dimension of job satisfaction have the highest Cronbach's alpha reliability value $(\alpha 0,77 ; \alpha 0,84)$. It is in line with the results of the reliability of the SAQ-A questionnaire by Sexton et al. (2003), ${ }^{9}$ which shows that the dimensions of job satisfaction are dimensions that obtain the highest reliability values among the other dimensions with a very reliable category ( $a$ o.86). The high reliability value of job satisfaction proves that health workers at the Puskesmas are satisfied with their current work and their workplace environment.

The dimension of cooperation climate in the Indonesian version of SAQ-A also gets a high Cronbach's alpha value ( $\alpha$ 0.869). These results indicate that the dimension of cooperation climate has been very reliable to measure the culture of collaboration among health workers. In the original instrument by Sexton et al. (2003), ${ }^{9}$ the dimension of cooperation climate also gets high reliability values $(\alpha 0,82)$ after the job satisfaction dimension. However, according to the results of the reliability in the adaptation of SAQ into Malaysian language, it was found that the 
dimension of the cooperation climate had the highest reliability value ( $\alpha$ 0.914) compared to other dimensions. ${ }^{5}$ This can happen considering the culture and values adopted by the community have differences between one country and another.

The reliability results that was low in this study are in the dimensions of stress recognition, outpatient care processes, and perceptions related to management, in which Cronbach's alpha results from all three dimensions are $<0.70$ (see Table 1.). his condition is almost similar to the results of the study of Haerkens et al. (2016), ${ }^{17}$ and Gabrani et al. (2015), ${ }^{19}$ in which the value of reliability from the stress recognition dimension and managementrelated perceptions is less than 0.70. Gabrani et al. (2015), ${ }^{19}$ stated that the results of reliability below 0.70 occur because of data missing that can affect the results of reliability. Meanwhile the reliability value of the SAQ questionnaire developed by Sexton et al. (2003), ${ }^{9}$ showed that there was 1 dimension with an alpha value $<0.70$ which was in the dimensions of working conditions ( $a$ 0.68). This proves that culture, social relations, and values adopted by health workers in a country can influence the value of reliability test results in the same questionnaire in different countries.

Differences in reliability results between Sexton et al. (2003), ${ }^{9}$ and this study can be seen from the lowest Cronbach's alpha value, in this study the stress recognition dimension is the dimension with the lowest reliability value among the other dimensions ( $a$ 0.612). In this dimension, it consists of 4 statement items that measure health workers' awareness of the stressful conditions when the workload is considered high. It aimed that individuals who are able to recognize the work stress that they experience are expected to be able to overcome so that unexpected events do not occur in the patient's care process. The lowest reliability value indicates that the statement items in that dimension are not yet homogeneous, so the respondent's answers have not been consistent enough. For this reason, revision of statement items can be considered to get a reliability value of> 0.80 .

Overall, the reliability results of the Indonesian version of the SAQ-A questionnaire (ISAQ-A) based on Cronbach's alpha per dimension were lower than that the version of Sexton et al. (2003). ${ }^{9}$ Similar results were experienced in the process of adaptation of SAQ into Albanian and Dutch, in which the reliability results have a lower value compared to the original version. ${ }^{17,19}$ However, if seen from the value of the overall item reliability, the Indonesian version of SAQ-A (ISAQ-A) has a very high reliability value which indicates that the questionnaire is very reliable for measuring the safety culture of health workers at the Puskesmas (a 0.914) (see Table 2).

\section{CONCLUSION}

The validity of the Indonesian version of the SAQ-A questionnaire based on I-CVI and S-CVI was 1.00 with the value of Cronbach's alpha reliability of 6 dimensions was in the range a $0.612-0.881$. The reliability test result for all Indonesian version of SAQ-A items was a 0.914 which means that the Indonesian version of the SAQ-A questionnaire (ISAQ-A) was a valid and reliable questionnaire for measuring the safety culture behavior by health workers in primary health care facilities.

\section{REFERENCE}

1. Westbrook J, Rob M, Woods A, Parry D. Errors in the Administration of Intravenous Medications in Hospital and the Role of Correct Procedures and Nurse Experience. BMJ Qual Saf, 2011; 20 (12): $1027-1034$

2. Schelbred A-B, and Nord R. Nurses' Experiences of Drug Administration Errors. J Adv Nurs, 2007; 60 (3): 317-324.

3. Silviyah A, Kapalawi A, dan Noor B. Penilaian Pengelolaan Budaya Keselamatan Pasien di RSUD Haji Makasar. Repository Universitas Hasanudin. 2014. Diakses $24 \quad$ April 2018 http://repository.unhas.ac.id/handle/123456789 $/ 10965$

4. Colla J, Bracken A, Kinney L, \& Weeks W. Measuring Patient Safety Climate: A Review of Surveys. Qual Saf Health Care, 2005; 14 (5): 364 366.

5. Hamid H, Kar C, Murad N. Adaptation and Validation of Safety Attitude Questionnaire (SAQ) in Malaysian Healthcare Setting. J Psikologi Malaysia, 2016; 30 (1): 17-29.

6. Flin R, Burns C, Mearns K, Yule S, \& Robertson E. Measuring Safety Climate in Health Care. Qual Saf Health Care, 2006; 15 (2): 109-115.

7. Singla A, Kitch B, Weissman J, \& Campbell E. Assessing Patient Safety Culture: A Review and Synthesis of the Measurement Tools. J Patient Saf, 2006; 2 (3): 105-115.

8. Robb G, \& Seddon M. Measuring the Safety Culture in a Hospital Setting: A Concept Whose Time Has Come. J New Zeal Med Assoc, 2010; 123 (1314): 66-76.

9. Sexton B, Thomas J, \& Grillo P. The Safety Attitudes Questionnaire guideline for administration. Texas: The University of Texas. 2003;

10. Bondevik G, Hofoss D, Hansen E, \& Deilkas E. The Safety Attitudes Questionnaire - Ambulatory 


\section{mutiara \\ medika}

Version: Psychometric Properties of the Norwegian Transalted Version for the Primary Care Setting. BMC Health Serv Res, 2014; 14 (1): 139.

11. Modak I, Sexton J, Lux T, Helmreich R, \& Thomas E. Measuring Safety Culture in the Ambulatory Setting: The safety Attitude Questionnaire-Ambulatory Version. J Gen Intern Med, 2007; 22 (1): 1-5.

12. Emilia O. Sikap Mengenai Keselamatan pada Residen dan Perawat di Rumah Sakit Pendidikan. J Manajemen Pelayanan Kesehatan, 2011; 14 (4): 191-196.

13. Aini Q. The Influence of Workload and Work Stress to Patient Safet Attitude on Nurses. J Biol, Agriculture, and Healthcare, 2014; 4 (28): 93-101.

14. Saosa V, and Rojjanasrirat W. Translation, Adaptation and Validation of Instruments or Scales for Use in Cross-Cultural Health Care Research: A Clear and User-Friendly Guideline. J Eval Clin Pract, 2011; 17 (2): 268-274.
15. Beaton E, Bombardier C, Guillemin F, \& Ferraz B. Guidelines for the Process of Cross-Cultural Adaptation of Self-Report Measures. Spine, 2000; 25 (24): 3186-3191.

16. Polit D, and Beck CT. The Content Validity Index: Are You Sure You Know What's Being Reported? Critics and Recommendations. Res Nurs Health, 2006; 29 (5): 489 -497.

17. Haerkens M, Leeuwen W, Sexton B, Pickkers P, Hoeven J. Validation of the Dutch Language Version of the Safety Attitudes Questionnaire (SAQ-NL). BMC Health Serv Res, 2016; 16 (385): $1-8$.

18. Kaya S, Barsbay S, \& Karabulut E. The Turkish Version of the Safety Attitudes Questionnaire: Psychometric Properties and Baseline Data. Qual Saf Health Care, 2010; 19 (6): 572-577.

19. Gabrani A, Hoxha A, Simaku A, Gabrani J. Application of the Safety Attitudes Questionnaire (SAQ) in Albanian Hospitals: A Cross-Sectional Study. BMJ Open, 2015; 5: e006528. 